\section{Voyage Around Franz Josef Land}

THE remarkable feat of circumnavigating the icegirt Franz Josef Land in a small motor vessel is reported by Science Service of Washington, D.C. Prof. N. N. Subov, arguing from temperatures in the Barents Sea in recent years that the arctic branch of the North Atlantic drift was unusually warm and would reduce the amount of ice around Franz Josef Land, set out last August from Murmansk in a hundred ton motor boat with 30 days' fuel and 40 days' stores. The tour, which was made from east to west, actually took thirty-four days. A large number of soundings and salinity observations were taken. A few small corrections in the map were also made.

\section{Announcements}

Sir Rrchard GLAzEBRook, formerly chairman of the Aeronautical Research Committee, has been awarded the gold medal of the Royal Aeronautical Society.

AT a meeting of the Council of the Royal Society of Edinburgh held on March 6, the following prizes were awarded: The Makdougall-Brisbane prize for $1930-32$, to Dr. A. C. Aitken, of the University of Edinburgh, for various contributions to mathematics published in the Proceedings of the Society ; Gunning Victoria Jubilee prize, for 1928-32, to Sir James Walker, for his numerous contributions to physical and general chemistry. The Bruce-Preller lecture for 1933 will be delivered by Prof. C. H. Lander, on October 23, on the subject of the utilisation of coal.

Mr. P. M. S. BlacketT will deliver the G. J. Symons memorial lecture of the Royal Meteorological Society on March 15 at 7.30. The subject of the lecture will be "Cosmic Radiation".

THE annual general meeting of the British Medical Association will be held in Dublin on July 25-29, under the presidency of Prof. T. G. Moorhead, regius professor of physic at Trinity College, Dublin.

A symposium on the utilisation of coal has been arranged by the British Science Guild, to be held on March 27 at the Royal Institution under the chairmanship of Mr. H. T. Tizard. The speakers include Capt. B. Acworth, Mr. S. Lacey, Eng.-RearAdmiral W. Scott Hill and Mr. A. C. Hardy. The discussion will be opened by Dr. O. M. W. Sprague.

THE Committee on Thermochemistry of the Union Internationale de Chimie proposes to publish an intermational table of thermo-chemical data. The Secretary of the Committee would be glad if authors who have published papers on thermochemistry within the last five years would send him two copies of their papers. Such copies should be sent to Dr. L. J. P. Keffler, The University, Liverpool.

Ax the annual general meeting of the Society of Public Analysts held on March 1 the following officers were elected for 1933 :-President : Mr. F. W. F. Arnaud; Past Presidents on the Council :
Mr. E. Richards Bolton, Dr. J. T. Dunn, Dr. Bernard Dyer, Mr. Edward Hinks, Mr. P. A. Ellis Richards, Mr. G. Rudd Thompson, Dr. J. Augustus Voelcker; Vice-Presidents : Mr. John Evans, Mr. H. M. Mason, Dr. G. W. Monier-Williams, Mr. George Stubbs. Hon. Treasurer : Mr. E. B. Hughes ; Hon. Secretary : Mr. G. Roche Lynch.

IN the paragraph in NATURE of March 4 (p. 300) entitled "Photographic Analysis of Explosion Flames", the velocity of detonation is incorrectly given, through an error in typing, as "one or two metres per second"; it should read "one or two miles per second".

UNDER the terms of the Thomas Gray Memorial Trust, the Council of the Royal Society of Arts has awarded the $£ 100$ prize, offered in 1932 for an essay on the rescue, by another vessel, of passengers and crew of a sinking vessel, to be equally divided between Commander R. D. Binney, Chief Officer J. W. Murphy, Lieut.-Commander D. A. Stride and Lieut.Commander J. H. Walker. For the $£ 100$ prize offered for any valuable improvement in the science or practice of navigation, nothing of sufficient merit was submitted, but an award of $£ 50$ was made to Ablebodied Seaman J. Patteson for a device designed by him and entitled "The Harmonic Constant Tide Calculator".

SEISMOMETRICAL reports on the earthquakes felt and recorded in Tokyo are now issued by the Earthquake Research Institute. We have received the first two numbers dealing with the earthquakes of January-June, 1932. Each of them includes a map of the origins of the earthquakes (thirty in number) felt in Tokyo, showing that they lie in, and to the north of, the Bay of Tokyo, except four in the wellknown zone that lies under the Pacific to the east of the Boso peninsula. Copies of the more important seismograms are also reproduced.

Applications are invited for the following appoint ments on, or before, the dates mentioned:-An assistant engineer for the River Avon (Bristol) Catchment Board-The Clerk and Solicitor to the Board, The Council House, Bristol (March I3). A principal of the Gloucester Technical College-The Clerk to the Governors, 24, Barton Street, Gloucester (March 16). An assistant borough electrical engineer and a temporary constructional engineer in the Electricity Department of the Fulham Borough Council--The Town Clerk, Town Hall, Fulham, S.W.6 (March 16). A divisional engineer (electrical) in the Department of the Chief Engineer of the London County Council-The Clerk of the Council, The County Hall, Westminster Bridge, S.E. (March 17). A lecturer in medicine at the University of Aberdeen-The Secretary (March 21). A professor of civil engineering at Trinity College, Dublin-The Secretary of the University Council (March 31). A ballistic assistant for mathematical work in relation to trajectories of projectiles-The Secretary (C.E. Branch), Admiralty, S.W.1. 